\title{
Hanford, Diversification, and the Tri-Cities Economy FY 1999
}

Prepared for the U.S. Department of Energy

Assistant Secretary for Environmental Management

Project Hanford Management Contractor for the

U.S. Department of Energy under Contract DE-ACO6-86RL13200

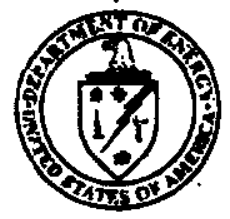

United States

Department of Energy

P.O. Box 550

Richlend, Washington 99352 
DOE/RL-2000-32

Revision 0

\section{Hanford, Diversification, and the Tri- Cities Economy FY 1999}

R.K. Stewart

U.S. Department of Energy

Date Published

May 2000

Prepared for the U.S. Department of Energy

Assistant Secretary for Environmental Management

Project Hanford Management Contractor for the

U.S. Department of Enorgy under Contract DE-ACO6-96RL13200

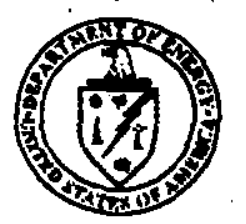

\section{United States}

Department of Energy

P.0. Box 550

Rlchland, Washington 99352

Phinetine Ytollenghend 5-10-99 


\section{LEOAL DHCCLAMER}

This report was prepared as an account of work sponsored by an agency of the United States Govemment. Netther the Uniced States Government nor any agancy thereof, nor any of their employece, nor any of thak contractors, wbeontractors or their employece, makes any warranty, express or Implled, or cacumes any legal bability of reaponeibility for the accuracy. completeness, or any third party's uae or the results of such use of any information, apparatus, product, or process dieclosed, or represents that its wee would not infringe pitvately ownod tighte. Reference herein to any spectife commereial product, proceses, or service by trade name, trademark. manufacturer, or otherwies, does not neceasarily constitute or Imply lts endoreament, recommendation, or favoring by the United states Covernment or any agency thereof or th: contractore or eubcontractors. The views and opinions of authors expreaend horein de not necesearily stato or refiect thase of the United Stutes Government or any saeney thereof.

This report has been reproduced from the best available copy. 


\section{INFORMATION CLEARANCE FORM}

\begin{tabular}{ll}
\hline \multicolumn{2}{c}{ A. Information Category } \\
$\square$ Abstract & $\square$ Joumal Artele \\
$\square$ Summery & $\square$ Internet \\
$\square$ Visual Ald & $\square$ Soltware \\
$\square$ Full Paper & $\square$ Roport \\
$\square$ Other
\end{tabular}
B. Dooument Number $D O E / R L-2000-32$
C. THte
If an Ford, Diversification, and the
Tri-Cidies Fconomy-FY 1995

\section{Intornat Address}

\section{E. Required Information}

1. Is gocument potentially clasulfed? $X$ No $\square$ Yos (MANDATORY) $\frac{142 \text { lelow }}{\text { Manager'signature Riquirad }}$

If Yes $\square$ No $\square$ ros Claseified ADC Signature Required

2. Internal Roview Requirod? if Yes, Documeni Signaturas Below

Counsel

Program

3. Reterences in the Information are Applied Technology $\mathbf{X}_{\text {No }} \square$ Yas

Export Controlled Information No $\square$ Yer

4. Does Information Contain the Fallowing: (MANDAJORY)

a. Now or Novel (Palentublo) Subject Matter? 4 No $\square$ Yas

If "Yos", Dinclosure No.:

b. Information Racalved in Confidance, Such as Propriatiry and/or inventions?

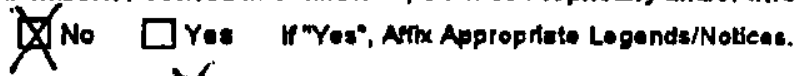

c. Copyrightar $\mathbb{X}$ No $\square$ Yes If "Yas", Attuch Parmission.

d. Tradomarkse? No $\square$ Yas "Yos", Identily in Doeument.

5. Is Information requiting wubmisaion to OSTH? $\quad$ No $\square$ Yos

If Yes UCand $B \in R$ -

\section{Robara Levol? $X$ Public $\square$ Limited}

7. Charge Code

F. Comploto for a Joumal Article

1. Tilin of Journal

G. Complete for a Presentation

4. Titue for Conference or Meeting

2. Group Sponsoring

3. Date of Conference

5. Will Information be Published in Proceedings? $\square$ No $\square$ Yas

H. Aythorkequegtor $R$. Dtement

R. K. Stewart

(Print and Sign)

I. Revlewers

Yes Print

4. CIty/state

6. Will Material be Handed Out? $\square$ No $\square$ Yes
General Counsel
$\mathbf{Z}$
R. Southworth
(Y) $\mathrm{N}$
Ofice of External Affalrs
m. Marvini..
(ช) $/ \mathrm{N}$
DOE-RL

$\square$
Other
$\square$
Othar

$\square$

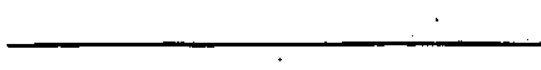
$Y / N$
$Y / N$
$\mathrm{Y} / \mathrm{N}$ Responsibie Manager

J. If Information includes Sunsitve information and la not to be released to the Publle indleato category below.
$\square$ Appliad Tochnology
$\square$ Protected CRADA
$\square$ Personal/Pilvale
$\square$ Export Contralled
Q Propiletary
$\square$ Procurement-Sensitive
$\square$ Busineas-Sensiltve
$\square$ Patentabla
$\square$ Predecisional
Other (Specily)
$\square$ UCNI 
A. Information Category

$\square$ Abstract

$\square$ summary

$\square$ Visual Ald

$\square$ Full Paper

$\square$ other

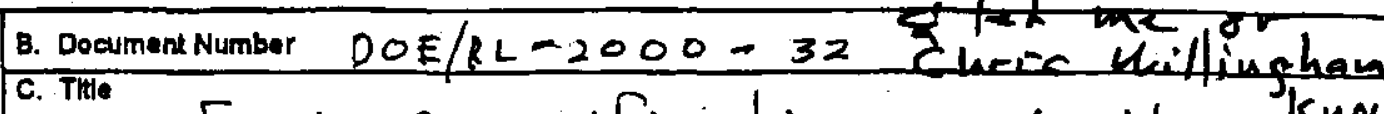
C. THe . Ford Diversi Picilion and the know If an ford, Diversitication, and the Tri-Ci ives fonomy F F is

\section{E. Requlsed Inlormation}

1. Is document potentlally Classihed? \No $\square$ Yea (MANDATORY)

\section{Managers signature Requirad}

If Yes

$$
\text { ADC Signature Raquired }
$$

2. Internal Revlew Regulred?

if Yes, Document Slgnature: Below

No $\square$ Yas Classified

XNo $\square$ Yes

Counsel

Program

3. References in the Information are Applied Technalogy Export Contralled Information
4. Does information Contain the Following: (MANDATORY):

a. Now or Novol (Palantablo) Subject Matter? $\$$ No $\square$ Yas

If "Yes". Disciosure No.:

b. Infosmalion Recolved in Confldance, such as Propriotary and/or Inventions?

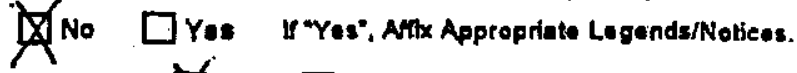

c. Copyrighter $X$ No $\square$ Yes if "Yos", Attueh Pormission.

d. Tradamerks? No $\square$ Yos "Yos", Identity in Decument.

5. Is information requiring aubmlacion lo OSTI? $\quad$ No $\square$ Yes

If Yas UCand $B G R$ -

6. Relases Level? $\mathbb{X}$ ( Public $\square$ Limited

7. Charge Code

\section{F. Complote for a Joumal Artele}

1. Tille of Journal

\section{G. Complate for a Prosentation}

1. Title for Conference or Meeting

2. Group Sponsoring

3. Dale of Conlerence

5. Will Iniormation be Published in Proceedings? $\square$ No $\square$ Yes

4. Cily/State

H. A $R$ thor/Requegtor $K$. Pterent

R.K. Stewart

(Prlnl and Sign)

B. Will Material be Handed Out? $\square$ No $\square$ Yes

l. Revlewers Yes Print

General Counsel

R. Southworth

Omee of Externsilaffeirs

M. Marvin:.

DOE-RL

Other

Othar

$\square$

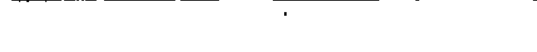

Respondbla Managar._____.....-

J. If Inlopmation Indudes Sensilve Information and ls not to be released to the Publle indiato catagory below.
$\square$ Applied Technology
$\square$ Protucted CRADA
$\square$ personalpilvate
$\square$ Export Controlled
$\square$ Proprietary
$\square$ Procuroment-Sensitive
$\square$ Businasesensitive
$\square$ Patentable
$\square$ Predeclsional
$\square$ othet (Specily)

$\square$ UCNI 
INFORMATION CLEARANCE FORM

515100 range) Can you clear this ( fish ar fot $^{\text {th }}$

\begin{tabular}{|ll}
\hline \multicolumn{2}{|c|}{ A.' Information Category } \\
$\square$ Abstract & $\square$ Joumal Article \\
$\square$ summary & $\square$ Internet \\
$\square$ Visual Ald & $\square$ Soliwere \\
$\square$ Full Paper & $\square$ Report \\
$\square$ Other &
\end{tabular}

E. Requifed information

1. Is document potentlahy Clateined? $\mathbb{X}$ No $\square$ Yes (MANDATORY) Manager's Signature Required

If Yes ADC Signature Required

$\square$ No $\square$ res Ciassifled

2. Internal Roview Regulred?

if Yes, Document Slgnature Bolow XNo $\square$ Yes

Counsel

Program

3. Refereneas in the Information are Applied Technology $\$ No $\square$ Yes Export Controlled information 区No $\square$ Yer

\section{D. inturnet Addrass}

B. Document Numbar $D O E / R L-2000-32$

c. Thle .
Bur
the

$$
\text { Tri-Cidies Economy - FY } 1933
$$

F. Complete for a Joumal Artelo

3. Titic of Journgl

G. Complato for a Prosentation

1. Title for Confarence or Meeting

2. Group Sponsoring

3. Date ol Conierenco

4. Clly/State

5. Wil information be Published in Proceedings? $\square$ No $\square$ Yes

6. Will Matorial be Handed Oun $\square$ No $\square$ Yes

H. Aythor/Requestor $R \cdot$ Dtumat

(Prinl and Sign)

1. Reviewers

Yes Print

Responelbio Manager

- Now or Novel (Patentable) Subject Mattor $\quad 4$ No $\square$ Yes

If "Yos", Disclosure No.:

b. Information Roeelved in Confidenca, such as Proprietery and/or Inventlona? 'Xf(No $\square$ Yes. If "Yes", Arix Appropriate Legenda/Notices.

c. Copyrighter $\mathbb{X}$ No $\square$ Yos If -Yas", Attach Pormission.

d. Tradoimarkar No $\square$ Yos If "Yos", Identify in Documant.

5. Is Information requiring aubmisolon to OSTI? . F No $\square$ Yos

If Yes $D C-$ and $\boldsymbol{B} \boldsymbol{A R}$ -

6. Relonen Levil? X( Public $\square$ Limited

7. Charge Code

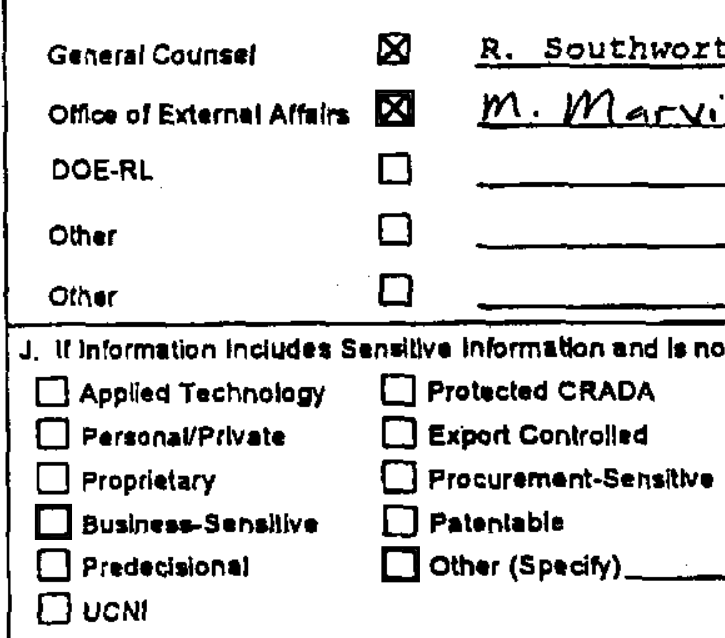

K. II Additional Comments, Please Attach Separate sheat 
s

\section{Hanford, Diversification, and the Tri-Cities Economy}

FY 1999

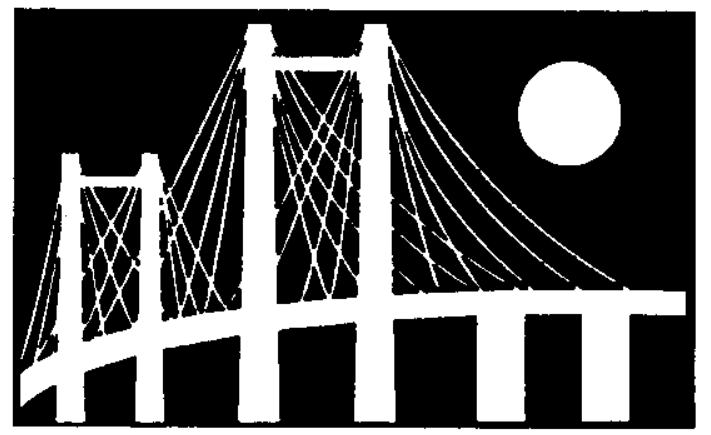

Published June 2000

U.S. Department of Energy, Richland Operations Office

Richland, Washington

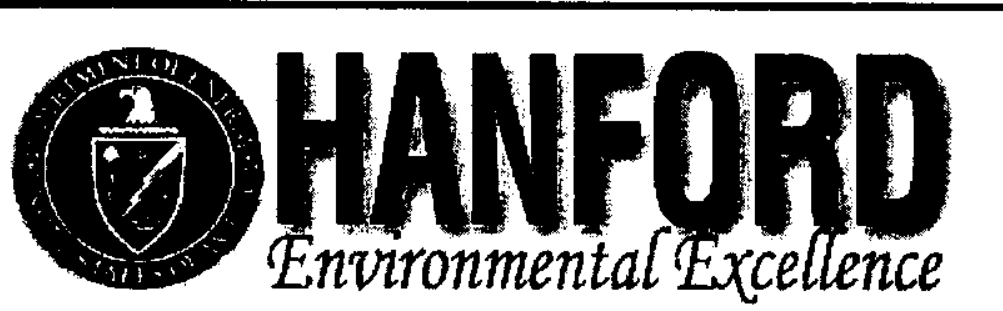




\section{Department of Energy \\ Richland Operations Office \\ P.O. Box 550 \\ Richland, Washington 99352}

\section{JUN 052000}

Growing a strong, diverse, and healthy economy is a high priority goal of the Tri-Cities community. Over the past $50+$ years, the community has experienced significant cyclical periods of economic growth and downturns due to varying levels of federal funding for Hanford activities. In recent years, the Department of Energy (DOE) and its contractors have been partnering with the community to support their effort to grow new businesses and attract new industries.

This report, which was prepared for DOE and which updates similar information provided for FY 1997 and FY 1998, relates how the diversification efforts paid off in FY 1999. It also provides encouraging information about FY 2000.

DOE and its contractors are pleased to be contributing to the community's efforts that are helping diversify the local economy, and look forward to continued progress and success.

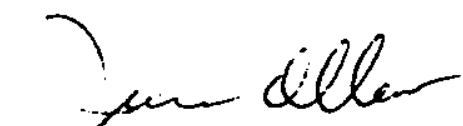

June E. Ollero, Director

Office of Training Services and Asset Transition 


\section{At a Glance: Hanford's Role in the Tri-Cities Economy, FY 1999}

- U.S. Department of Energy (DOE) and its contractors continue to have a more significant impact on the Tri-Cities economy than any other entity. In fiscal year (FY) 1999, Hanford's payrolls and local purchases of goods and services directly contributed about $\$ 768$ million to the local economy. Through direct Hanford employment or indirect jobs stemming from Hanford work, DOE's FY 1999 budget of $\$ 1.59$ billion accounted for about $32 \%$ of all local employment, up to $44 \%$ of local wages and $35 \%$ of local earnings (labor and proprietor income). This is a slight decrease from previous years. The large apparent decline in wage percentage from previous reports mainly reflects a correction of a programming error in the previous version of the model discovered during the model update. Revised estimates for FY 1997 and FY 1998 using the corrected model are provided in an appendix.

- The Tri-Cities Industrial Development Council and other local organizations, supported by DOE, have contributed significantly to community economic diversification. The fruits of these combined business recruitment and development efforts paid off in FY 1999 with almost 900 new direct local jobs and \$27 million in earnings. In FY 2000, continuing economic development activities by all organizations are estimated to result in almost 400 additional direct jobs and about $\$ 13$ million in earnings.

- DOE budget increases in FY 2000 to about $\$ 1.64$ billion are not expected to affect Hanford employment but should increase payrolls and local procurements. This additional spending should result in about 1,050 additional jobs and $\$ 60$ million in earnings in the Tri-Cities community. This additional employment would be reflected in services such as independent technical and consulting services, construction, manufacturing, and real estate.

- Additional good news is that strong economic diversification efforts by DOE, its contractors, and community organizations are adding growth on top of DOE's currently stable base. These new sources of growth are expected to directly add 400 additional jobs and $\$ 13$ million in additional earnings in the community in FY 2000, for a total direct and indirect impact of 650 jobs and $\$ 20$ million in earnings. One potential cause for concern is that this is far below the pace of a year ago.

- Adding the impact of this Hanford and non-Hanford growth to a slightly better year in agriculture results in a strong increase in FY 2000 of about 3,750 jobs and $\$ 180$ million in earnings.

- DOE and its contractors have played a significant role in economic diversification by providing economic transition funding and in-kind assistance. Examples include support of facilities for business startups and technology commercialization; assistance for new businesses; transfer of manufacturing equipment to municipal, commercial, and educational organizations; privatization of Hanford activities; support of Hanford staff entrepreneurial programs; and partnerships with investors to encourage outside industries to locate to the community. 


\section{Contents}

Summary

1

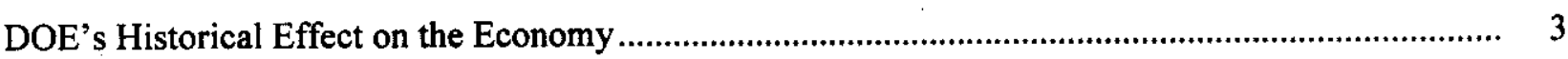

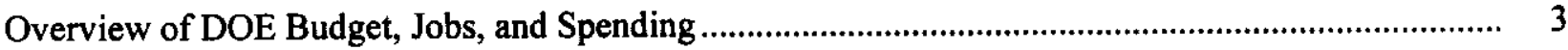

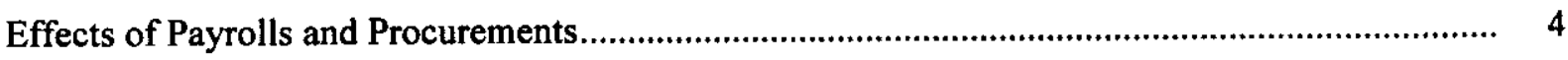

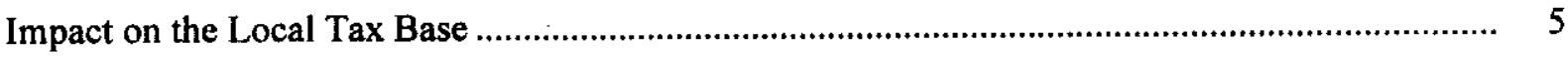

Population, Schools, Public Services, and Infrastructure ........................................................ 5

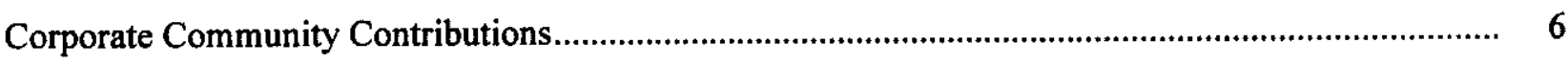

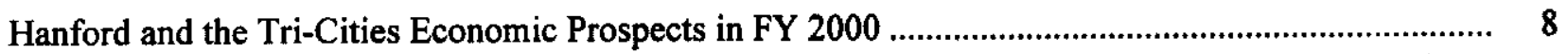

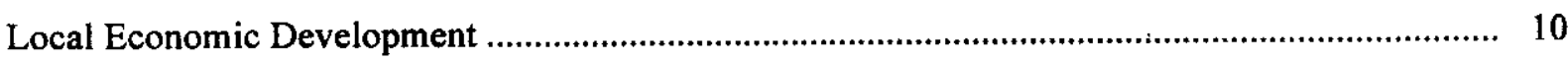

$\mathrm{DOE} / \mathrm{RL}$ and Contractor Economic Transition Programs ...................................................... 10

User Facilities and New Science and Technology Missions .................................................... 12

Tri-Cities Non-Hanford Business Recruitment and Development Efforts, FY 1999 ................... 13

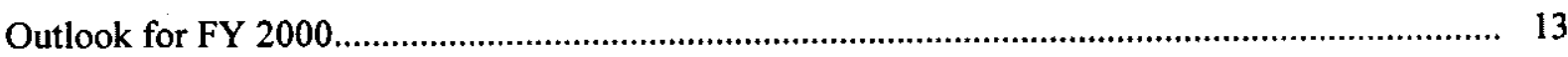

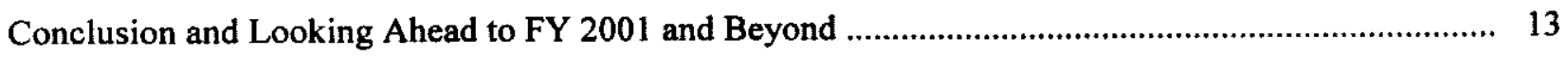

Appendix: Model Update and Correction of FY 1997 and FY 1998 Impact Estimates ...................... A.1 


\section{Figures}

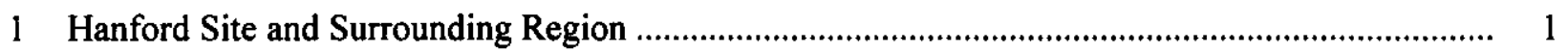

2 Total Tri-Cities Non-Agricultural Employment vs. Employment in Key Sectors......................... 2

3 DOE/RL Contractor Procurements in the Tri-Cities by Selling Industry, FY 1999 .................... 4

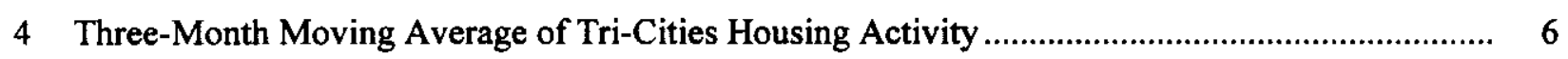

\section{Tables}

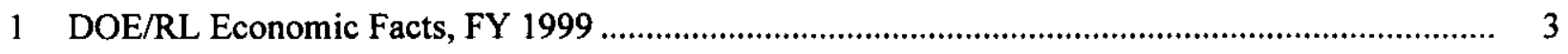

$2 \mathrm{DOE} / \mathrm{RL}$ and its Contractors are the Largest Element in the Tri-Cities' Economic Base .............. 4

3 DOE Payments in Lieu of Taxes and Contractor and Employee Tax Payments to Local

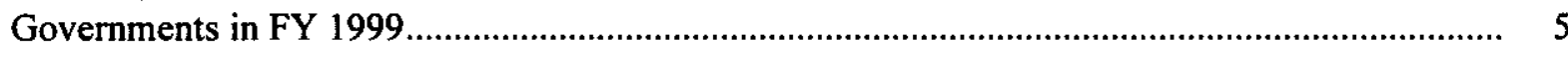

4 Population, Schools, Public Services, and Infrastructure .................................................. 5

5 The Tri-Cities Economy in FY 2000 (Projected) …........................................................ 8

6 Selected Statistics for DOE/RL and Contractor Economic Transition Programs, FY 1999 ........... 11

7 User Facilities and New Science, Technology, and Training Missions, FY 1999 ..................... 12

8 Tri-Cities New Facilities plus Non-Hanford Business Recruiting and Development Statistics,

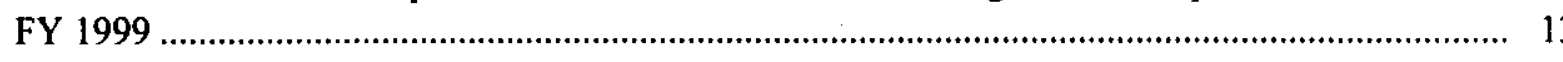




\section{Hanford, Diversification, and the Tri-Cities Economy FY 1999}

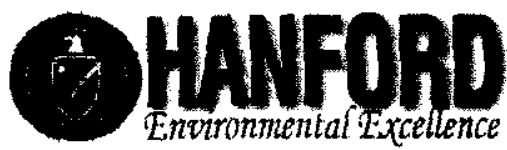

The Hanford economic region is centered on Benton and Franklin counties (shaded area).

\section{Summary}

The missions of the U.S. Department of Energy's Richland Operations Office (DOE/RL) are to safely manage the Hanford Site, to manage and clean up its legacy wastes, and to develop and deploy new science and technology in the environmental and energy fields. Collectively, $\mathrm{DOE} / \mathrm{RL}$ and its contractors are the most important single entity in the Tri-Cities local economy (Pasco, Kennewick, and Richland, Washington, and the surrounding area). Although the relevant economic region affected by DOE/RL and its contractors actually embraces a geographic area reaching from Yakima in the west to Walla Walla in the east and from Moses Lake in the north to Pendleton, Oregon, in the south, over $90 \%$ of economic impacts likely occur in Benton and Franklin Counties. These two counties are defined as the "local" Tri-Cities economy for purposes of this study (see Figure 1).

In the federal fiscal year (FY) 1999 (October 1, 1998 through September 30,1999), the total impact of DOE's local $\$ 1.59$ billion budget was felt through payrolls of $\$ 542$ million and local purchases of goods and services of \$226 million. The total local spending of $\$ 768$ million was up slightly from the FY 1998 total of $\$ 765$ million. Taking into account the multiplier effects of this spending, the DOE/RL budget sustained an estimated $32 \%$ of all local employment $(28,250$ out of 88,100 jobs) and about $35 \%$ of local earned incomev(almost

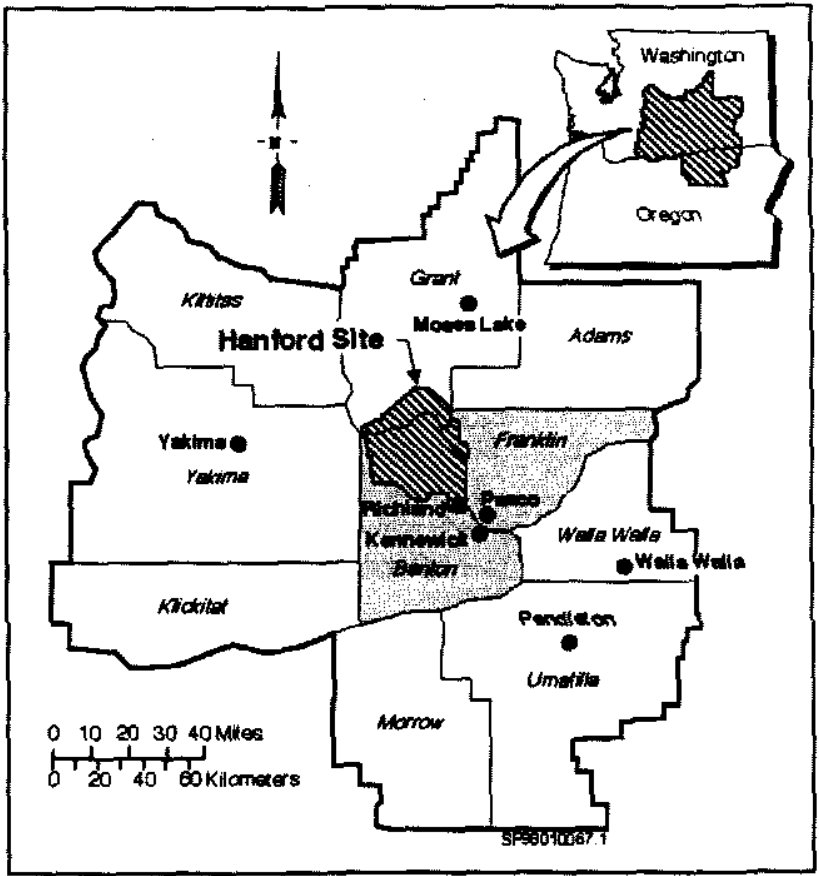

Figure 1. Hanford Site and Surrounding Region 


\section{Multiplier Effect}

Hanford expenditures have a direct effect on employment in the community. As workers spend their wages and DOE and its contractors purchase goods and services in the community, they generate additional, non-Hanford retail and service jobs and income. This is known as the multiplier effect. Together, the direct plus indirect effects are called total effects. Besides DOE, other local industries with these multiplier effects include agriculture, other industrial employers, and regional services.
$\$ 1.08$ billion out of $\$ 3.08$ billion). The decrease in these percentages from last year's report reflects an update of the model's economic structure based on the 1997 economic census year, a correction of a programming error in the model found during the update, and a broader definition of earnings that includes proprietor income, not just wages (see the Appendix for revisions to the previous forecasts). DOE budget increases in FY 2000 are expected to result in no change to the number of local DOE contractor jobs and about a $\$ 29$ million increase in direct local spending.

Economic diversification directly added almost 900 jobs and $\$ 27$ million in earnings to the Tri-Cities economy in FY 1999, while the privatization of the Hanford tank waste cleanup directly added another 450 jobs and $\$ 26$ million in earnings. The total impact of diversification was 1,450 jobs and $\$ 41$ million in earnings, and the total impact of privatization was about 1,000 jobs and $\$ 40$ million in eamings. In FY 2000 , new direct employment of almost 400 jobs from diversification and an additional direct increase of about 250 jobs in privatization of Hanford's tank waste cleanup are expected. All of these positives, taken together with their multiplier effects, would directly or indirectly add a total 2,250 jobs and at least $\$ 100$ million in income to the economy. Although still weak, agriculture likely will have a better year than in FY 1999 and boost related regional services. The overall net effect of all factors together is expected to be a total increase of 3,750 jobs and $\$ 180$ million in earnings in the Tri-Cities in FY 2000.

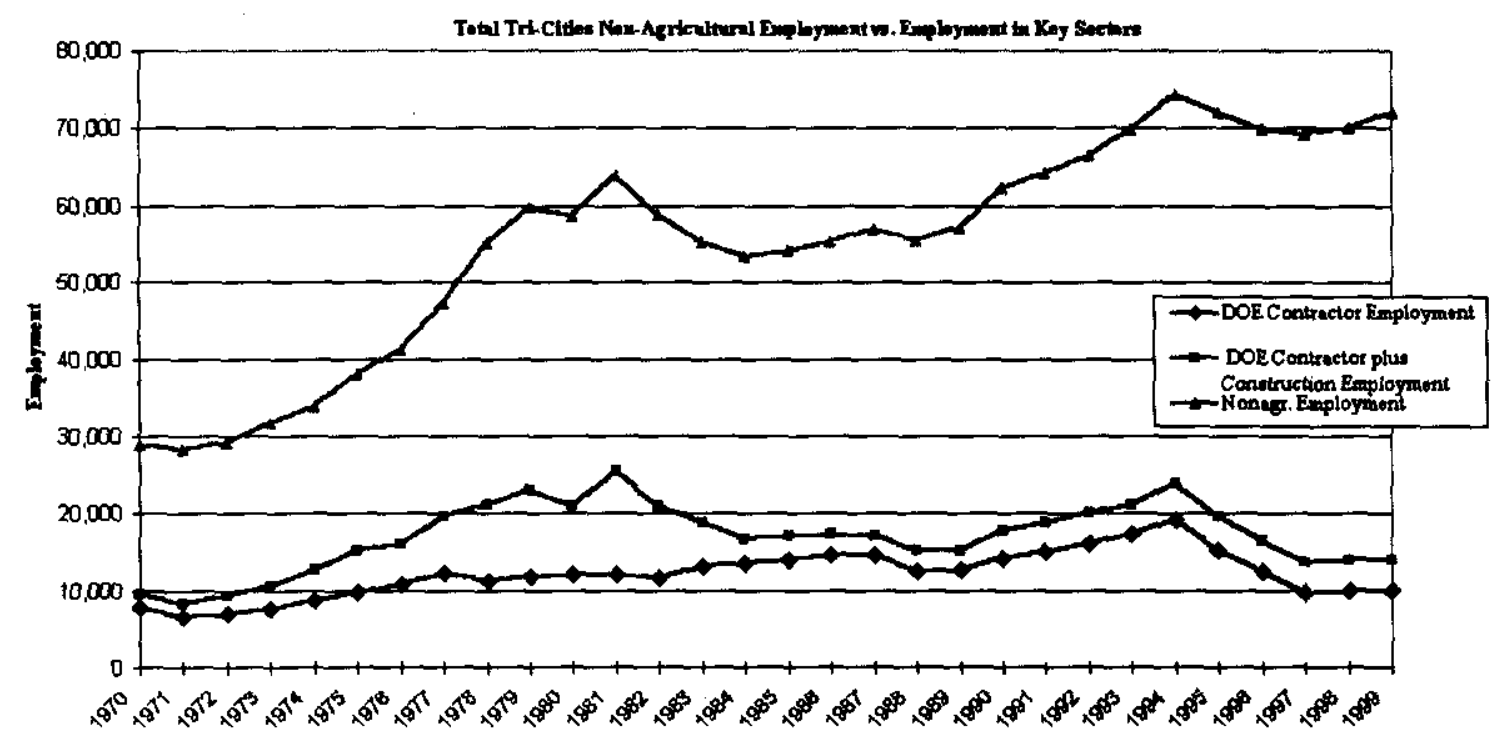

Figure 2. Total Tri-Cities Non-Agricultural Employment vs. Employment in Key Sectors 


\begin{tabular}{|c|c|}
\hline \multicolumn{2}{|c|}{ FY 1999 Budget Authority (Million \$) } \\
\hline $\begin{array}{l}\text { Current Environmental } \\
\text { Management (EM) Activities }\end{array}$ & $\$ 1,112$ \\
\hline Non-EM Programs & $\$ 374$ \\
\hline $\begin{array}{l}\text { Tank Wastes Privatization (not } \\
\text { available for current spending) }\end{array}$ & $\$ 100$ \\
\hline Total FY 1999 Budget & $\$ 1,586$ \\
\hline \multicolumn{2}{|l|}{ Employment (Annual Average) } \\
\hline Federal & 500 \\
\hline Contractors & 9,900 \\
\hline \multicolumn{2}{|l|}{ Spending (Million \$) } \\
\hline Payroll & $\$ 542$ \\
\hline Local Procurements & $\$ 128$ \\
\hline $\begin{array}{l}\text { Spending at Affiliate } \\
\text { Companies } \\
\text { (formerly Enterprise } \\
\text { Companies) }\end{array}$ & $\$ 98$ \\
\hline
\end{tabular}

\section{DOE's Historical Effect on the Economy}

Ever since the early 1940s, the economy of Benton and Franklin Counties in the state of Washington has been highly dependent on the level of activity at DOE contractors operating the Hanford Nuclear Reservation (otherwise known as the Hanford Site) and the nearby Pacific Northwest National Laboratory (PNNL). For example, Figure 2 shows that nonagricultural employment since 1970 has closely mirrored DOE contractor employment except in the late 1970s and early 1980s, when nuclear power plant construction also was a significant factor.

The Hanford Site mission has since changed to one of environmental cleanup and restoration. To better serve this new mission, in $1996 \mathrm{DOE}$ changed the management of Hanford to a Project Hanford Management Contract (PHMC) that integrates a group of specialty firms under the general management of an integrating contractor, and added the Office of River Protection in 1999. This change has significantly changed the balance between Site employment and procurements, altering Hanford's role in the regional economy. As the Hanford Site completes its environmental mission over the next few years, the level of activity at Hanford is expected to decline significantly. The local community in Benton and Franklin Counties has begun a process of diversification on several fronts to reduce the region's dependency on the Hanford Site and to replace the declining Hanford portion of the area's economic base.

Many organizations and individuals are interested both in the current impact of DOE/RL and its contractors on the Tri-Cities economy and in the progress of local economic diversification efforts. This report provides a comprehensive view of the economic role of DOE/RL and its contractors in the Tri-Cities economy during FY 1999 and discusses the impact of the diversification efforts to date.

\section{Overview of DOE Budget, Jobs, and Spending}

The government authorized the spending of over $\$ 1.5$ billion at Hanford and PNNL in FY 1999 (Table 1). The total was about $\$ 60$ million more than in FY 1998 and reflected the lower stabilized level of funding that has prevailed since FY 1994 and FY 1995, when the total local DOE budget was $\$ 1.9$ billion. About $70 \%$ of the FY 1999 budget was spent for current Environmental Management (EM) activities, while the second biggest component, non-EM programs, mainly reflects the numerous and diverse science and technological development projects at PNNL. The $\$ 100$ million for tank wastes privatization reserve is part of EM funding, but is a set-aside amount not available for current spending.

DOE/RL employed an average of 500 federal employees and 9,900 contractor employees during FY 1999. By year's end, contractor employment had decreased slightly to 9,833 . In FY 1998, the year before, average contractor employment was 9,900 and year-end employment was 9,633 . At the end of FY 1999, about $150-200$ jobs of the 1,700 jobs at the affiliate companies were non-Hanford jobs. 


\begin{tabular}{|l|}
\hline Table 2. DOE/RL and its \\
Contractors are the Largest Element \\
in the Tri-Cities' Economic Base \\
\hline Total Impacts, FY 1999 \\
\hline $\begin{array}{l}\text { Impact of Con- } \\
\text { tractor Payrolls on } \\
\text { Tri-Cities } \\
\text { Employment }\end{array}$ \\
\hline $\begin{array}{l}\text { Impact of Con- } \\
\text { tractor Payrolls on }\end{array}$ \\
Tri-Cities Income
\end{tabular}

The DOE budget affects the local economy both through purchases of goods and services by DOE/RL and its contractors and through spending of payroll dollars by their employees. For example, in FY 1999 the DOE/RL contractors spent almost $\$ 128$ million on procurements in the Tri-Cities. Of this amount, roughly $79 \%$ was for various business services, $13 \%$ for trade, and about $1 \%$ for construction (Figure 3). The site also bought $\$ 98$ million worth of services from the affiliate companies in FY 1999. The Tri-Cities captured about $39 \%$ of all DOE/RL contractor procurements in FY 1999.

\section{Effects of Payrolls and Procurements}

Even after recent downsizing, the Hanford Site was still the largest single source of employment in the Tri-Cities at the end of September 1999 , with 9,833 direct employees. The number employed is the smallest since 1975 , but still represents roughly $11 \%$ of the jobs in the economy and directly represents about $21 \%$ of the total wage income in the area. Direct procurements plus subcontracts by the DOE contractors represented of $\$ 226$ million, or $12 \%$ of the total sales in the Tri-Cities economy during FY 1999, about the same as the year before.

PNNL has recently corrected and updated its Tri-Cities economic model to validate against the 1997 local inter-industry sales, payrolls, and other spending. In FY 1999, the revised model shows that about 21,350 Tri-Cities jobs depended directly or indirectly on the Hanford payroll and about 6,900 on procurements and the affiliate company contracts, for a total of 28,250 (Table 2). This is $32 \%$ of the non-farm jobs in the economy. About $44 \%$ of wages and $35 \%$ of the non- farm wage and proprietor earnings ( $\$ 1.08$ billion out of $\$ 3.08$ billion) may depend directly or indirectly on Hanford payrolls and spending. Revised FY 1997 and FY 1998 impacts are in the Appendix.

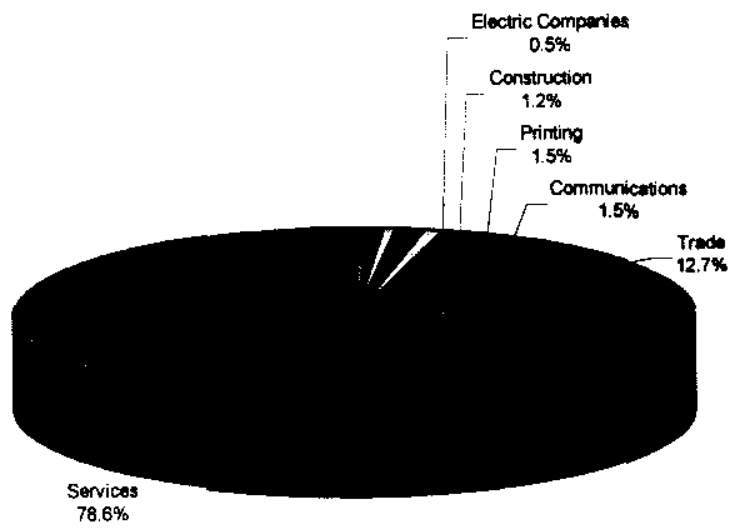

Figure 3. DOE/RL Contractor Procurements in the Tri-Cities by Selling Industry, FY 1999 


\begin{tabular}{|c|c|}
\hline Source & Am \\
\hline $\begin{array}{l}\text { DOE Payments in Lieu } \\
\text { of Taxes }\end{array}$ & $\$ 6.7$ million \\
\hline $\begin{array}{l}\text { Contractor Sales and Use } \\
\text { Taxes }\end{array}$ & $\$ 2.2$ million \\
\hline $\begin{array}{l}\text { Contractor Property } \\
\text { Taxes }\end{array}$ & $\$ 0.9$ million \\
\hline $\begin{array}{l}\text { Employee Sales and Use } \\
\text { Taxes (Local Share) }\end{array}$ & $\$ 7.0$ million \\
\hline $\begin{array}{l}\text { Employee Property } \\
\text { Taxes (Local Share) }\end{array}$ & $\$ 23.9$ million \\
\hline
\end{tabular}

Table 4. Population, Schools, Public Services, and Infrastructure

\begin{tabular}{|c|c|}
\hline Economic Factor & Year and Value \\
\hline $\begin{array}{l}\text { Total Population, } \\
\text { Benton and Franklin } \\
\text { Counties }\end{array}$ & $\begin{array}{l}1994-169,900 \\
1995-175,000 \\
1996-174,700 \\
1997-177,900 \\
1998-181,900 \\
1999-184,000\end{array}$ \\
\hline $\begin{array}{l}\text { Head Count School } \\
\text { Enrollment, Benton } \\
\text { and Franklin Counties } \\
\text { School Districts }\end{array}$ & $\begin{array}{l}1994-37,073 \\
1995-37,549 \\
1996-38,180 \\
1997-38,541 \\
1998-38,851 \\
1999-39,202\end{array}$ \\
\hline $\begin{array}{l}\text { Recent Average } \\
\text { Housing Values by } \\
\text { Fiscal Year }\end{array}$ & $\begin{array}{l}1994-\$ 119,200 \\
1995-\$ 112,700 \\
1996-\$ 109,500 \\
1997-\$ 115,300 \\
1998-\$ 115,700 \\
1999-\$ 123,400\end{array}$ \\
\hline $\begin{array}{l}\text { Housing Starts by } \\
\text { Fiscal Year }\end{array}$ & $\begin{array}{r}1994-1,117 \\
1995-\quad 433 \\
1996-667 \\
1997-557 \\
1998-\quad 639 \\
1999-\quad 748\end{array}$ \\
\hline $\begin{array}{l}4^{\text {th }} \text { Quarter Apartment } \\
\text { Vacancies, Tri-Cities, } \\
\text { by Fiscal Year }\end{array}$ & $\begin{array}{r}1994-5.0 \% \\
1995-11.5 \% \\
1996-18.0 \% \\
1997-12.0 \% \\
1998-10.0 \% \\
1999-6.0 \%\end{array}$ \\
\hline
\end{tabular}

\section{Impact on the Local Tax Base}

The DOE contractors mainly conduct work for the federal government in facilities owned by the federal government. This work generally is not subject to Washington State sales taxes, nor are the federal facilities on the tax rolls. Instead, the federal government makes payments in lieu of taxes to local governments and taxing districts. In FY 1999, the federal government disbursed a total of $\$ 6.7$ million (Table 3). The contractors paid \$2.2 million in local sales and use taxes (use taxes are paid on use of selected equipment instead of the sales tax), as well as $\$ 0.9$ million property taxes on their own property (for example, Battelle, which operates PNNL, owns \$36 million worth of facilities in north Richland). Also, contractors paid \$6.5 million in Washington State Business and Occupations Tax and some portion of taxes paid on rental facilities owned by private companies (data are not readily available on these items). Finally, based on their incomes, the employees of DOE and the contractors paid an estimated $\$ 7.0$ million in sales taxes and an estimated $\$ 23.9$ million in property taxes. In all, direct Hanford-related taxes in FY 1999 represented about $23 \%$ of sales and use taxes in Benton and Franklin counties and about $20 \%$ of total local property tax.

\section{Population, Schools, Public Services, and Infrastructure} Historically, changes in employment at Hanford have been one of the major drivers of change in the population of Benton and Franklin counties. From 1994 to 1999 , however, it appears that there was a change in this relationship. Despite the loss of some 9,350 positions at Hanford (from 19,200 in July 1994 to under 9,850 by September 1999), and a corresponding decline in total nonagricultural employment $(75,500$ in September 1994 to 71,900 in September 1999), population in the area has actually risen (Table 4). The demographers at the state of Washington Office of Financial Management estimate that the population of Benton and Franklin counties increased from 169,900 in 1994 to 184,000 in 1999. The reasons for this increase are not clear, although selfemployment, retirements, movement in some families from two incomes to one, and growth of the general region (especially Umatilla County, Oregon) clearly play a role. The increase in population also is reflected in the school-age population for the 10 local public school districts in the two-county area (private schools enroll an additional 2,200 students).

The accompanying chart of Tri-Cities housing prices for the last 10 years (Figure 4) shows the effect of Hanford on the real estate market during that time, especially 1989-1994 (3-month averages are used to smooth month-to-month volatility). Beginning with the start of downsizing in July 1994, prices initially declined, then recovered and stabilized. Table 4 data on housing starts show that there was considerable fall-off in construction from 1994 to 1995 . Construction has since recovered, reflecting the fact that the population and economy have not declined with this downturn in DOE contractor employment. Data on the rental markets for the area initially reflected a general softening, but recovery seems underway there, as well. 


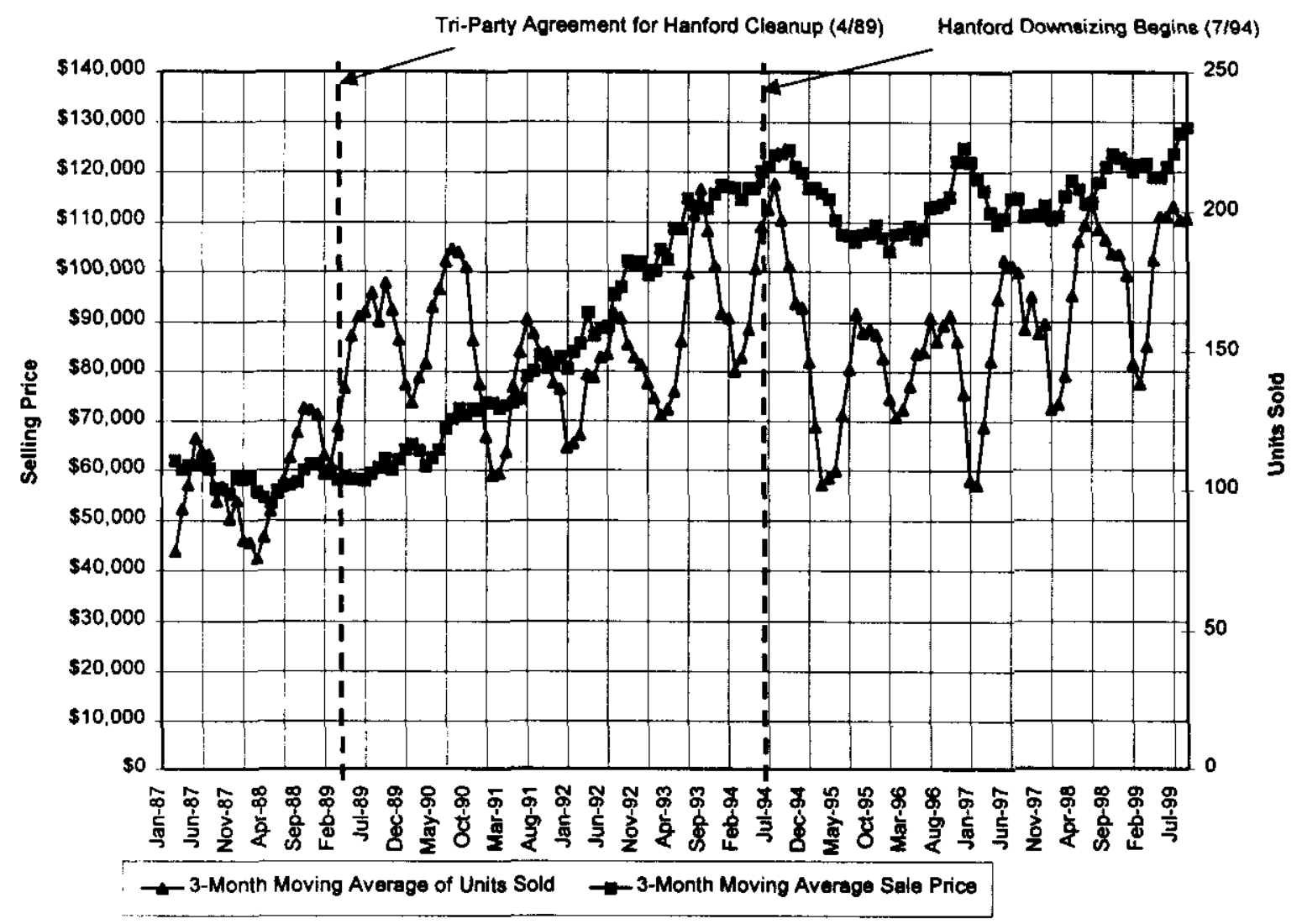

Figure 4. Three-Month Moving Average of Tri-Cities Housing Activity

\section{Corporate Community Contributions}

The DOE contractors and DOE/RL play a major role in the community as corporate citizens. In FY 1999, the PHMC contractors gave nearly $\$ 1.4$ million to charities and organizations, more than $\$ 1.1$ million of which was in Benton and Franklin counties. While accurate statistics are not kept on volunteer time, DOE and DOE contractor employees donated thousands of hours to the community:

- PHMC volunteers donated almost 2,500 hours on weekends and after work from May to September putting in landscaping to benefit The Children's Center. The facility at the Richland $\mathrm{Y}$ is the new home of the Benton-Franklin Child Developmental Center and Head Start of Benton \& Franklin Counties. Besides a cash donation of $\$ 5,000$ from the PHMC Team, this project saved The Children's Center tens of thousands of dollars in expenses that would have been incurred for procured commercial services to meet occupancy permit requirements to open the facility.

- PHMC volunteers coordinated the community-wide Thanks-4Giving Book Harvest-more than 78,000 books (compared to 60,000 last year) were collected for the Tri-Cities Reading Foundation and the Washington State Reading Corps/ 
Foundation and the Washington State Reading Corps/ AmeriCorps, and then distributed to four local hospitals, over 1,000 day-care providers, senior centers, schools, and libraries.

- In addition, the PHMC donated $\$ 5,000$ to The Reading Foundation to support their literacy goals. This was added to an $\$ 8,000$ çontribution by FDH, FDNW, and the Fluor Foundation for the Reading Foundation's "Books for Babies" program which provides every newborn in the Tri-Cities with their first book and an educational package for parents describing the value of reading to their children.

- The PHMC championed and organized the first annual Tri-City Crystal Apple Awards for Excellence in Education for recognizing and celebrating outstanding teachers in the seven local public school districts. With over 40 co-sponsors lead by the PHMC companies and DOE, ten teachers or teams of teachers were each awarded $\$ 1,000$, a Crystal Apple, and other prizes. The event garnered Senator Slade Gorton's Award for Innovation in Education.

- Battelle total corporate contributions in the Pacific Northwest were $\$ 714,000$ to a variety of community and philanthropic organizations. Of that total, about $\$ 627,000$ went to the greater Tri-Cities, while the remainder, $\$ 87,000$, went to locations outside of those counties. The latter figure includes amounts that went to schools in the Yakima valley.

- Battelle has developed a decentralized, staff-driven volunteer program known as Team Battelle, which has focused and coordinated more than 4,800 contributed hours from staff who volunteer after-hours in the community. Current projects include March of Dimes/Walk America, and American Cancer Society Relay for Life, Tumbleweed Music Festival, Junior Achievement, Habitat for Humanity, child car seat safety checks, Tapteal Greenway, Earth Day 2000, adult day care services, and others.

- Several hundred DOE and contractor staff members devote their time to bring science and technology to the local school systems through programs such as the Science Bowl, Sharing Science with Schools, Engineers' Week, and career days. More than 200 staff are also formally employed as adjunct faculty at Washington State University Tri-Cities and at Columbia Basin College.

- The DOE/RL and its contractors also donate millions of dollars of excess but serviceable equipment such as personal cormputers to schools and other community organizations each year and make available some of their auditorium facilities for meetings of community organizations. FY 1999 asset transfers included $\$ 6.9$ million in assets transferred to federal and state agencies, $\$ 2.2$ million in computers donated to schools in Washington, Oregon, and Montana, and \$27.9 million in equipment sold through public sales (mostly to small local businesses). Large asset transfers this year included three cranes: a 10-ton bridge crane, a 3-ton bridge crane, and a $1 / 4$-ton jib crane. 


\begin{tabular}{|c|c|}
\hline \multicolumn{2}{|c|}{$\begin{array}{l}\text { Table 5. The Tri-Cities Economy } \\
\text { in FY } 2000 \text { (Projected, April 1999) } \\
\text { DOE/RL }\end{array}$} \\
\hline Budget & $\begin{array}{l}\$ 1,636 \\
\text { million }\end{array}$ \\
\hline \multirow{2}{*}{ Contractor Employment } & 9,850 \\
\hline & $\$ 571$ million \\
\hline Local Procurements & $\$ 136$ million \\
\hline Local Subcontracts & $\$ 105$ million \\
\hline \multirow{2}{*}{$\begin{array}{l}\text { Direct plus indirect } \\
\text { impacts on the Economy } \\
\text { of increase from } \\
\text { FY } 1999 \text { (including } \\
\text { multiplier effects) }\end{array}$} & $\begin{array}{r}+1,050 \text { total } \\
\text { jobs }\end{array}$ \\
\hline & $\begin{array}{r}+\$ 60 \text { million } \\
\text { earnings }\end{array}$ \\
\hline \multicolumn{2}{|c|}{$\begin{array}{l}\text { Other Sectors' Impacts on the } \\
\text { Economy }\end{array}$} \\
\hline \multirow[t]{2}{*}{ Agriculture } & $\begin{array}{r}+850 \text { total } \\
\text { jobs }\end{array}$ \\
\hline & $\begin{array}{r}+\$ 62 \text { million } \\
\text { earnings }\end{array}$ \\
\hline \multirow[t]{2}{*}{ Regional services } & $\begin{array}{r}+650 \text { total } \\
\text { jobs }\end{array}$ \\
\hline & $\begin{array}{r}+\$ 14 \text { million } \\
\text { earnings }\end{array}$ \\
\hline \multirow[t]{2}{*}{ BNFL-Inc. } & +550 jobs \\
\hline & $\begin{array}{r}+\$ 24 \text { million } \\
\text { earnings }\end{array}$ \\
\hline $\begin{array}{l}\text { Traditional Major } \\
\text { Employers }\end{array}$ & No Change \\
\hline $\begin{array}{l}\text { New science and user } \\
\text { facilities }\end{array}$ & No Change \\
\hline \multirow[t]{2}{*}{$\begin{array}{l}\text { New enterprises and } \\
\text { expansions }\end{array}$} & $\begin{array}{r}+650 \text { total } \\
\text { jobs }\end{array}$ \\
\hline & $\begin{array}{r}+\$ 20 \text { million } \\
\text { earnings }\end{array}$ \\
\hline \multirow[t]{3}{*}{$\begin{array}{l}\text { Total Net Impact, All } \\
\text { Sectors }\end{array}$} & $\begin{array}{r}3,750 \text { total } \\
\text { jobs }\end{array}$ \\
\hline & $\begin{array}{r}+\$ 180 \\
\text { million } \\
\text { earnings }\end{array}$ \\
\hline & \\
\hline
\end{tabular}

\section{Hanford and the Tri-Cities Economic Prospects in FY 2000}

The Hanford Site is emerging from transition, stemming from changes in management approach, downsizing in its workforce, and division of responsibilities between the Office of River Protection and DOE/RL. Fiscal year 2000 promises a $3.2 \%$ increase in budget with associated increases in impact. Overall, the expected local FY 2000 DOE budget of approximately $\$ 1.636$ billion (which includes $\$ 100$ million set aside for privatization of the Hanford Site's high-level nuclear waste operations that will not be used to fund current projects) should sustain a contractor workforce of more than 9,850 and local procurements and subcontracts of about $\$ 241$ million, if current employment and procurement patterns hold. This would mean about the same employment as September 1999 and no change relative to the FY 1999 average employment, an increase of $\$ 28$ million in payroll, and an increase of \$14 million in local procurements and subcontracts. For the community as a whole, other things equal, the impact would be to increase FY 2000 employment in the whole community (including Hanford) by 1,050 jobs and wage income by $\$ 60$ million over the FY 1999 average.

Contributions from other sectors are expected to add to these gains. The other large employers of the Tri-Cities and some new enterprises continue to have a significant positive impact on growth in the twocounty region, independent of the Hanford Site. This is expected to be helped by a slightly better year in agriculture.

Agriculture: An increase of $18 \%$ in Benton and Franklin county farm proprietor and labor income to about $\$ 284$ million appears possible due to better potato and apple prices, even though the outlook for several of the region's major crops is flat to down compared with a very disappointing year in 1999 . The disappointment was due largely to continued problems in the region's traditional Asian markets, more vigorous competition in home markets from Asia, problems with food import regulations in Mexico, and political constraints on some international sales. Soft white wheat prices are expected to be down from last year's average value of around $\$ 3.00$ to $\$ 3.25$ per bushel to the $\$ 2.50$ to $\$ 2.70$ range as a result of continued high stocks and good weather in the Great Plains, coupled with continued difficulties in Asian markets (which are recovering) and strengthening of the dollar against Asian currencies. Com prices are projected to decline from about $\$ 2.35$ to a range of $\$ 1.80$ to $\$ 2.00$ per bushel.

Southeast Asian demand is expected to grow about $6 \%$ this year in contrast to the $6 \%$ decline in 1998, while Latin America grows about $2.7 \%$, and western Asia and North Africa deal with drought. However, corn and soft white wheat prices are still expected to be at the lowest levels since 1986/87. Market prices for milk are forecasted by the USDA/ERS to be approximately $12 \%$ below 1999 , the lowest level since 1990/91. The price is expected to be below $\$ 12.00$ early in the year. Potato prices are expected to be up this year, in part 
because of a smaller Canadian crop. Prices are expected to be between $\$ 5.40$ and $\$ 6.40$ per hundredweight (cwt). Dry bean prices are down between $13 \%$ and $20 \%$, due to problems with Mexico accepting exports from the U.S.

The outlook is better for apple prices in the U.S. this year because of the relatively small Washington crop in 1999 (down 23\%). Prices at the end of 1999 were as much as $27 \%$ above the year earlier (the U.S. average was $\$ 320 /$ ton), and stocks of red delicious were down $15 \%$ by the end of the year. In addition, Chinese apple juice concentrate is now subject to a preliminary anti-dumping duty of $55 \%$, which should help domestic growers in the juice market. Concord grapes have been steady in price the last 4 years and should not change much. Wine grapes have steadily declined in price since 1997 , and the steady introduction of new producing vines (especially chardonnay and merlot) should continue the trend, reducing the weighted average price to around $\$ 900 /$ ton from $\$ 910$ in 1999 . Most vegetable prices are expected to remain relatively flat, due to high stocks, weak exports, and flat domestic demand. Fed-cattle marketings are expected to remain near record high levels. Beef prices are expected to be about $5 \%$ higher than in 1999 , remaining in the vicinity of $\$ 67$ to $\$ 69 / \mathrm{cwt}$ during the spring and summer, increasing into the low- $\$ 70$ range by late fall. Pork has gone above $\$ 40 / \mathrm{cwt}$. Fuel prices are up considerably this spring, which will add to costs of production. Taken together, a slightly better year in agriculture will add about $18 \%$ to farm labor and proprietor income and about 850 total jobs and \$62 million in total earnings to the economy.

Other Major Employers: Fiscal year 1999 saw the emergence of British Nuclear Fuels, Inc. (BNFL-Inc.), the U.S. subsidiary of British Nuclear Fuels Ltd., as a major employer in the Tri-Cities economy. BNFL-Inc. has the mission of vitrifying Hanford's high-level radioactive wastes for long-term storage. However, the company is not counted as a Hanford contractor because its activity is not reflected in the current Hanford budget. The current contractual arrangement calls for BNFL-Inc. to design, construct, and operate the required facilities at the company's own financial risk, while DOE pays only for the finished product beginning in the year 2007. During FY 1999, BNFLInc. and its direct subcontractors had an average employment of over 470 and local procurements of about $\$ 12$ million. Employment had increased from 200 in October 1998 to 720 by the end of September 1999, where it is expected to remain. This is an increase in annual average employment for this sector of about 250 jobs for FY 2000. The total impact is about 550 jobs and \$24 million in eamings. 
In FY 1999 the Tri Cities' traditional major employers collectively added fewer than 50 employees from the year before. As a group they expect to experience constant employment in the near term. This includes Energy Northwest (formerly, Washington Public Power Supply System), which expects to produce about the same level of power for the next five years with about 1,050 employees; Siemens, with constant employment at about 750 employees; Lamb Weston, with a constant level of 1,700 employees in Benton and Franklin counties; Sandvik, constant at about 270 employees; and lowa Beef Processors and Boise Cascade in western Walla Walla County, constant at about 1,700 employees and 700 employees, respectively. Depending on agricultural product prices, regional manufacturing exports should stay approximately constant at $\$ 1$ billion. Burlington Northern Railroad, which currently employs between 400 and 450 workers in the Pasco rail yard, has also leveled off after a recent aggressive hiring trend. Earnings among the area's traditional major employers are expected to be roughly constant.

\section{Local Economic Development}

Much of the new activity is a direct result of economic development programs and business recruitment and assistance programs conducted by the Hanford contractors, by the Tri-City Industrial Development Council (TRIDEC), and by a number of the local government entities in Benton and Franklin counties. While these groups performed much of this work with their own resources, economic transition funding and in-kind assistance from the DOE have also played a critical role. In FY 1999 , almost 900 jobs and about $\$ 27$ million in wage income were directly added to the economic base from these sources; current commitments to expansion and expected recruitment successes are expected to add almost 400 additional jobs and $\$ 13$ million in income in FY 2000. In FY 1999, the total impact was about 1,450 jobs and $\$ 41$ million in earnings. In FY 2000 the total impact is expected to be about 650 jobs and $\$ 20$ million.

\section{DOE/RL and Contractor Economic Transition Programs}

Six business strategies have been developed under DOE/RL's Hanford Economic Transition Program to support diversification of the local economy while helping to clean up Hanford.

1. Build strategic partnerships where economic collaboration and synergy are strong.

2. Leverage (match) existing site operations, technologies, and physical assets to "seed" private sector business opportunities and economic growth.

3. Invest in and build around community capabilities and strengths.

4. Provide a real return on investment in terms of cost reduction, technology infusion into cleanup, and creating business enterprises.

5 Align the Hanford Economic Transition Program with the Secretary of Energy's strategic goals, the Hanford Site mission, and local community economic development goals.

6 Strategically focus on the recruitment, expansion, and start-up of small business enterprises at Hanford. 


\begin{tabular}{|l|l|}
\hline \multicolumn{2}{|c|}{ Table 6. Selected Statistics for } \\
DOE/RL and Contractor Economic \\
Transition Programs, FY 1999
\end{tabular}

The DOE contractors also have their own economic development programs. The following are examples of economic transition and privatization efforts of DOE/RL and its contractors.

Economic Development Grants. A total of $\$ 21$ million has been granted since FY 1994 in the "3161" Program and related programs to fund community proposals intended to help diversify the local economy, including \$4.1 million in FY 1999 to TRIDEC. Including carryover funds, $\$ 2.4$ million was spent in FY 1999 by TRIDEC. Proposals funded by TRIDEC as a result of the grant include supporting the minority business development, WSU Tri-Cities Business Links, the Tri-Cities Enterprise Association's Entrepreneurial Support Network, the Southeastern Washington Development Association (SWDA) Equity Capital Fund, programs to enhance the Columbia River shore and to promote tourism, the PNNL Entrepreneurial Leave of Absence Program and Technical Assistance Program, TRIDEC marketing, and several other activities.

Facilities Reuse. DOE determined that the 1100 Area operating functions could be relocated or eliminated, therefore, making the 1100 Area available for transfer to a third party. In addition, until recently, many facilities on the Hanford Site were heated by steam generated by one of several coal-fired plants located on site. Under the Energy Savings Performance Contract, smaller package boilers were installed, and the coal-fired plants were shut down. Shipment of coal to the plants had been the primary use of the Hanford rail system. Once these shipments were no longer required, DOE determined that the Hanford rail system was no longer necessary for operation of the site.

The entire 1100 area is premium land zoned for industrial use. On October 1, 1998, the 1100 Area and the Southern Rail Connection of the Hanford Railroad were transferred to the Port of Benton for industrial development. 


\begin{tabular}{|c|c|}
\hline Activity & $\begin{array}{c}\text { Direct Economic } \\
\text { Impact }\end{array}$ \\
\hline $\begin{array}{l}\text { Laser Interferometer } \\
\text { Gravitational Wave } \\
\text { Observatory (LIGO) }\end{array}$ & $\begin{array}{l}20 \text { new staff } \\
\text { members, plus } \\
\text { visiting scientists }\end{array}$ \\
\hline $\begin{array}{l}\text { Willian R. Wiley } \\
\text { Environmental and } \\
\text { Molecular Sciences } \\
\text { Center (EMSL) }\end{array}$ & $\begin{array}{l}350 \text { outside } \\
\text { researchers. Time } \\
\text { onsite equivalent } \\
\text { to } 16 \text { full time staff } \\
\text { (No change from } \\
\text { FY 1998) }\end{array}$ \\
\hline $\begin{array}{l}\text { Applied Process } \\
\text { Engineering } \\
\text { Laboratory (APEL) }\end{array}$ & $\begin{array}{l}35-40 \text { direct jobs } \\
\text { (18-20 new) }\end{array}$ \\
\hline $\begin{array}{l}\text { Hazardous Materials } \\
\text { Management and } \\
\text { Emergency } \\
\text { Response } \\
\text { (HAMMER) } \\
\text { Training Center }\end{array}$ & $\begin{array}{l}\text { Outside students } \\
\text { equivalent to about } \\
13 \text { full-time } \\
\text { employees ( }+3 \\
\text { change from } \\
\text { FY 1998). } \\
\end{array}$ \\
\hline All Programs & $\begin{array}{l}84-89 \text { non- } \\
\text { Hanford direct } \\
\text { jobs ( } 41-43 \text { new) }\end{array}$ \\
\hline \multicolumn{2}{|l|}{ Impact on the Economy } \\
\hline Total Impact & $\begin{array}{r}75 \text { new jobs; } \\
\$ 3.2 \text { million in } \\
\text { earnings }\end{array}$ \\
\hline
\end{tabular}

User Facilities and New Science and Technology Missions Several new user facilities are operating at Hanford and PNNL. Combined, these facilities brought payrolls and spending equivalent to about 48 full-time employees in FY 1999 (Table 7). The Laser Interferometer Gravitational Wave Observatory (LIGO) has been completed. This $\$ 90$ million project will detect and measure gravitational waves. The facility houses approximately 20 staff members. LIGO is a joint project of the California Institute of Technology and the Massachusetts Institute of Technology. The National Science Foundation manages funding for the project.

PNNL's \$230-million William R. Wiley Environmental and Molecular Sciences Laboratory became operational in 1997. About 675 users from academia, other national laboratories, and industry conducted research in DOE's Environmental Molecular Sciences Laboratory in FY 1999, and nearly half of those were onsite at least part of the year, the equivalent of about 16 full-time staff. EMSL serves as a national collaborative research and technology laboratory, providing educational and training opportunities for future scientists.

The Applied Process Engineering Laboratory (APEL) is a joint project with DOE, TRIDEC, City of Richland, Port of Benton, PNNL, WSU/Tri-Cities, and Energy Northwest. The facility was refurbished and opened in FY 1998 to create a permitted, high-bay incubator that will spin off new technology-based enterprises focused on environmental remediation and pollution prevention. About 18 to 20 new jobs were created by companies occupying the APEL facilities during FY 1999. Total staffing at APEL is currently nearly 100 , of whom 35 to 40 are employees of non-Hanford companies.

Hanford's Volpentest HAMMER training center trains workers how to cope with massive chemical accidents and a range of other topics. More than 33,600 cumulative student days were logged during FY 1999. About $10 \%$ of the cumulative student days were attributable to non-Hanford personnel, or the spending equivalent of about 13 jobs. 


\begin{tabular}{|c|c|}
\hline \multicolumn{2}{|c|}{$\begin{array}{l}\text { Table 8. Tri-Cities New Faci } \\
\text { plus Non-Hanford Business } \\
\text { Recruiting and Development } \\
\text { Statistics, FY } 1999\end{array}$} \\
\hline Program or Facility & Direct Impact \\
\hline $\begin{array}{l}\text { DOE Contractor } \\
\text { Economic Development } \\
\text { Programs }\end{array}$ & +492 jobs \\
\hline $\begin{array}{l}\text { TRIDEC (In addition to } \\
\text { the jobs shared with } \\
\text { DOE Contractor } \\
\text { programs) }\end{array}$ & +60 jobs \\
\hline $\begin{array}{l}\text { Pasco Community } \\
\text { Development (In } \\
\text { addition to TRIDEC and } \\
\text { DOE Contractor shared } \\
\text { jobs) }\end{array}$ & +28 jobs \\
\hline $\begin{array}{l}\text { City of Richland (In } \\
\text { addition to TRIDEC and } \\
\text { DOE Contractor shared } \\
\text { jobs) }\end{array}$ & +190 jobs \\
\hline $\begin{array}{l}\text { Port of Benton (In addi- } \\
\text { tion to TRIDEC and } \\
\text { DOE Contractor shared } \\
\text { jobs) }\end{array}$ & +6 jobs \\
\hline $\begin{array}{l}\text { Port of Kennewick, } \\
\text { Kennewick Irrigation } \\
\text { District (In addition to } \\
\text { TRIDEC and DOE } \\
\text { Contractor shared jobs) }\end{array}$ & +40 jobs \\
\hline $\begin{array}{l}\text { Prosser Economic } \\
\text { Development } \\
\text { Association (In addition } \\
\text { to TRIDEC and DOE } \\
\text { Contractor shared jobs) }\end{array}$ & +25 jobs \\
\hline Subtotal, Non-Hanford & +841 jobs \\
\hline $\begin{array}{l}\text { New Missions, and User } \\
\text { Facilities }\end{array}$ & +42 jobs \\
\hline All Programs, FY 1999 & +883 jobs \\
\hline \multicolumn{2}{|l|}{ Impact on the Economy } \\
\hline & $\begin{array}{r}+1,450 \text { total jobs, } \\
+\$ 41 \text { million total } \\
\text { eamings }\end{array}$ \\
\hline
\end{tabular}

\section{Tri-Cities Non-Hanford Business Recruitment and Development Efforts, FY 1999}

DOE and TRIDEC have executed a Memorandum of Understanding (MOU) that designates TRIDEC as the "one voice" for the local community on economic development issues. The MOU allows DOE and the local community to develop, review, and prioritize economic development activities related to Hanford. TRIDEC currently represents 42 economic development entities in the Benton-Franklin county area. Several of the local governments have their own recruitment and community development programs that have resulted in the creation of additional investments and jobs beyond those claimed by and credited to DOE, DOE contractors, and TRIDEC diversification efforts.

Because business recruitment and development is a joint responsibility of many parties, many entities can justly claim joint credit for development successes such as Livingston Rebuild Center or Intemational Hearth Melting. Shared results are shown in Table 8. Combining all sources, after removing all double counting implicit in shared successes, almost 900 direct jobs paying about $\$ 27$ million were created. The bottom line is that the total impact from all sources of business recruitment and development efforts, including multiplier effects, was about 1,450 total jobs and $\$ 41$ million in earnings.

\section{Outlook for FY 2000}

Based on the FY 2000 budget, Hanford employment will be slightly larger than in FY 1999, and total payrolls should also be up slightly. Hanford procurements and subcontracts should increase, and BNFLInc.'s new activity will add at least 250 workers and an increase in payrolls of perhaps $\$ 14$ million. TRIDEC and the local governments are pursuing new leads for additional local direct jobs. Future expansions and new recruits in FY 2000 are expected to include at least 388 additional jobs, including about 100 in Richland retail, and over 240 in miscellaneous food processing, other light manufacturing and services. By itself, the overall community-wide impact of all of this activity would be an increase of about 2,600 total jobs and about $\$ 125$ million in total wage income in FY 2000. Although another tough year is expected in agriculture, agricultural income is expected to be slightly better in FY 2000 , contributing enough spending to support an additional 850 jobs and $\$ 22$ million in earnings. Regional services is expected to add about 650 jobs and $\$ 14$ million in earnings. Thus, overall, FY 2000 should see an increase of about 3,750 jobs over FY 1999 and total local labor and proprietor earnings should see an increase of about $\$ 180$ million.

\section{Conclusion and Looking Ahead to FY 2001 and Beyond}

The diversification of the local economy remains on track, but the challenges remain. As Hanford downsizing continues, the core Hanford budget is expected to continue to decline, slowly eliminating a major component of the Tri-Cities area's economic base. The local DOE budget request for FY 2001 is $\$ 2.062$ billion, of which $\$ 450$ million is expected to be set aside for privatization of high-level 
nuclear waste operations. The difference, $\$ 1.612$ billion, would again represent an increase from FY 1999 in dollars available for current spending.

The BNFL-Inc. proposal for Phase I of the high-level waste privatization process was adopted with changes in August 1998. BNFL-Inc. submitted its official proposal for the overall project in April 2000 with an estimated cost of $\$ 15.2$ billion. This cost estimate was much higher than previous estimates. On May 9, Secretary of Energy Bill Richardson announced that he was terminating the BNFL Inc. privatization contract. The DOE will seek new bidders and award a new contract by the end of this calendar year to complete the design work and to carry out the construction of the facility. During the transition period, the current design team will continue in order to avoid future delays. Because the design team is expected to stay together and over half of FY 2000 has already passed, the impact of this decision on economic activity in FY 2000 will be small, but would be important in FY 2001. If the project were implemented without loss of time, construction would begin in 2001 and would require about 2000 construction workers, followed by 600 operating personnel in the year 2007 . No other major projects have been announced in the local area.

Waste cleanup could provide a major short-run boost to the local economy over the next few years, but it will be necessary in any case to continue to develop a more permanent and more diverse economic base for the Tri-Cities area. Consequently, it is necessary for the community to continue and accelerate its diversification efforts, whose success appears to be slowing slightly in FY 2000. Continued success in creating and supporting local startups and continued recruiting efforts are vital to the Tri-Cities' economic future. 


\section{Appendix}

Model Update and Correction of FY 1997 and FY 1998 Impact Estimates 


\section{Appendix}

\section{Model Update and Correction of FY 1997 and FY 1998 Impact Estimates}

In the process of updating the Tri Cities economic model for this report, an error was found in the previous version of the model produced in 1997. The consequence of this error was a significant overestimate of the impact of increases in export activity in the economy, including the Hanford Site, which now has been corrected. In addition, the model was brought more up-to-date and tested against the 1997 economy (the last year for which complete employment and earnings data were available). Finally, a change was made to the model to better reflect the earnings of proprietors as well as those of wage and salary workers. The following table provides the original and revised estimates of the impact of Hanford in the Tri Cities economy for the last three fiscal years. The revised data show a slight decrease in economic importance of Hanford over the last three fiscal years, as well as a continued high (albeit smaller) absolute dependence.

Table A.1. Impact of Hanford on the Tri Cities Economy

\begin{tabular}{|l|l|l|l|}
\hline & \multicolumn{1}{|c|}{ FY 1997 } & \multicolumn{1}{c|}{ FY 1998 } & FY 1999 \\
\hline Original Estimate (FY 1997 and FY 1998 reports) & $\begin{array}{l}\text { No earlier } \\
\text { estimate }\end{array}$ \\
\hline Jobs & 30,300 & 31,200 & \\
\hline Wages (Million \$) & $\$ 1,491$ & $\$ 1,548$ & \\
\hline Percent of Local Jobs & $36 \%$ & $36 \%$ & \\
\hline $\begin{array}{l}\text { Percent of Local } \\
\text { Wages }\end{array}$ & $67 \%$ & $65 \%$ & \\
\hline & & & 28,250 \\
\hline Revised Estimate (This report) & 29,350 & 28,400 & $\$ 1,077$ \\
\hline Jobs & $\$ 1,094$ & 31,061 & $32 \%$ \\
\hline Wages (Million \$) & $35 \%$ & $44 \%$ & $42 \%$ \\
\hline Percent of Local Jobs & $49 \%$ & $36 \%$ & $35 \%$ \\
\hline $\begin{array}{l}\text { Percent of Local } \\
\text { Wages }\end{array}$ & $49 \%$ & \\
\hline $\begin{array}{l}\text { Percent of Local } \\
\text { Earnings }\end{array}$ & $38 \%$ & & \\
\hline
\end{tabular}

